REVIEW

\title{
Why cardiologists should be interested in air pollution
}

\author{
H C Routledge, J G Ayres, J N Townend
}

Heart 2003;89:1383-1388

Despite major improvements in air quality resulting from increasingly stringent legislation, there remains a strong association between daily mortality and current levels of air pollution. Growing epidemiological evidence suggests that many, perhaps the majority, of these deaths are caused by cardiovascular disease.

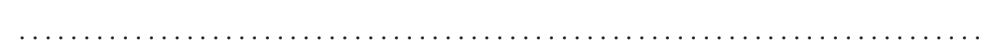

U rban air pollution is primarily derived from fossil fuel combustion and consists of both gaseous and particulate matter (PM) (table 1). Airborne particles are complex mixtures of elemental carbon, organic carbon compounds, and reactive components such as transition metals, metal oxides, acid condensates, sulfates, and nitrates. The particles believed to be most deleterious to health are those with an aerodynamic diameter of less than $10 \mu \mathrm{m}\left(\mathrm{PM}_{10}\right)$ although increasingly attention has focused on the ultrafine component $\left(\mathrm{PM}_{2.5}\right.$ and $\left.\mathrm{PM}_{0.1}\right)$, which can penetrate deep into the gas exchange region of the lung. Sulfur dioxide is largely derived from industrial sources while nitrogen dioxide and carbon monoxide are both vehicle derived. Ozone is an oxidant gas formed by the action of ultraviolet light on oxides of nitrogen and hydrocarbon fragments in vehicle emissions. All have been implicated in time series analyses as causes of adverse cardiovascular health effects (tables 1 and 2). ${ }^{1-16}$

\section{ACUTE CARDIOVASCULAR EFFECTS}

Examination of epidemiological data shows that while the relative risk for pollution related death is greater for respiratory than for cardiovascular causes, because of the size of the population at risk, the number of deaths is in fact greater for cardiovascular diseases ${ }^{17}$ (table 2). Although effect sizes vary greatly between studies, metaanalyses of the time series data suggest that an increase in fine particulate pollution of $10 \mu \mathrm{g} / \mathrm{m}^{3}$ is associated with an increase in total mortality of $1.8 \%$ and cardiovascular mortality of about $1.4 \%{ }^{67}$ Similar conclusions can be drawn from data on hospital admissions for cardiovascular disease (table 3). ${ }^{18-26}$ Findings from a London time series analysis were consistent with 1 in 50 myocardial infarctions treated at London hospitals being triggered by outdoor air pollution. By extrapolation, across the UK high levels of ambient pollution may be responsible for at least 6000 cardiovascular events per year. ${ }^{25}$ A systematic review of the time series data, prepared for the Committee on the Medical Effects of Air Pollutants, UK Department of Health, estimated that a $10 \mu \mathrm{g} / \mathrm{m}^{3}$ reduction in 24 hour average
$\mathrm{PM}_{10}$ concentration would be associated with a $0.8 \%$ reduction in cardiovascular admissions. ${ }^{27} \mathrm{~A}$ recent observation from Dublin suggests that these data may even underestimate the true benefit of achievable reductions in particulate pollution. A ban on coal sales in 1990 that reduced black smoke concentration by $35.6 \mu \mathrm{g} / \mathrm{m}^{3}$ was associated with a $10.3 \%$ decrease in annual cardiovascular mortality..$^{28}$ In a similar intervention study, a $50 \%$ reduction in sulfur dioxide concentrations following legal restrictions on fuel oil sulfur in Hong Kong was immediately followed by a $2.4 \%$ reduction in cardiovascular deaths. ${ }^{29}$

Survival analysis data derived from cohort studies have also defined the population that is most susceptible to the cardiovascular effects of air pollution. The highest risk appears to be in people with pre-existing cardiac disease. Goldberg and colleagues, ${ }^{30}$ for example, showed that daily mortality increased linearly with the concentration of ambient particles among people who had chronic coronary artery disease and congestive heart failure. While the relations between cardiovascular mortality and air pollution have been repeatedly shown, the precise causes of these deaths have been more difficult to determine. The majority of time series studies describe effects according to broad categories, relying on retrospective analysis of routine coding for both admissions and mortality. During a smog episode in West Germany in 1985, however, deaths and admissions were coded on the basis of the International classification of diseases for $94 \%$ of cases. ${ }^{1}$ Deaths from heart failure, myocardial infarction, and stroke were all increased significantly in the polluted compared with the control areas. Notably, arrhythmia admissions were increased by 50\% compared with the periods before and after the smog. ${ }^{1}$ More recently Hoek and colleagues ${ }^{31}$ studied associations between daily variations in air pollution and specific cardiovascular causes of death in the Netherlands over eight years. Effect sizes were significant for total cardiovascular mortality and deaths caused by myocardial infarction and other ischaemic heart disease, but were most pronounced (three times higher) for deaths caused by heart failure and arrhythmia. ${ }^{31}$

A panel study carried out by Peters and colleagues $^{32}$ adds further weight to the hypothesis that an increase in cardiac arrhythmia contributes to the rise in mortality associated with increases in ambient pollution levels. In 100 patients with implantable cardioverter-defibrillators in Boston in the USA, episodes of defibrillation were related to daily air pollution. The frequency of defibrillator discharges was 
Table 1 Sources of urban air pollution

\begin{tabular}{|c|c|c|c|}
\hline & $\begin{array}{l}\text { London annual hourly } \\
\text { average } 1996\end{array}$ & $\begin{array}{l}\text { Maximum daily UK } \\
\text { value } 1996\end{array}$ & EPAQS \\
\hline $\begin{array}{l}\text { Sulfur dioxide (ppb) } \\
\text { PM } 10\left(\mu \mathrm{g} / \mathrm{m}^{3}\right) \\
\text { Ozone (PB) } \\
\text { Nitrogen dioxide (PB) } \\
\text { Carbon monoxide (ppm) }\end{array}$ & $\begin{array}{l}8 \\
30 \\
16 \\
28 \\
1.4 \text { (roadside) }\end{array}$ & $\begin{array}{l}201 \\
380 \\
121 \text { (rural site) } \\
205 \\
15.8 \text { (roadside) }\end{array}$ & $\begin{array}{l}100 \text { (over } 15 \text { minutes) } \\
50 \text { ( } 24 \text { hour mean) } \\
50 \text { (8 hour running average) } \\
150 \text { (1 hour mean) } \\
10 \text { (8 hour running average) }\end{array}$ \\
\hline
\end{tabular}

Table 2 Time series analyses of pollutants causing adverse cardiovascular health effects

\begin{tabular}{|c|c|c|c|}
\hline Time series study & Geographic area & Pollutants & CVS mortality effect \\
\hline Wichmann $1985^{1}$ & West Germany 1985 & $\begin{array}{l}\mathrm{SO}_{2} \\
\mathrm{TSP}\end{array}$ & $\begin{array}{l}8 \% \uparrow \text { mortality during smog } \\
6 \% \uparrow \text { CVS mortality (15\% } \uparrow \text { admissions) }\end{array}$ \\
\hline Schwartz $1990^{2}$ & London 1958-1972 & Black smoke, $\mathrm{SO}_{2}$ & Significant predictors of all cause mortality \\
\hline Katsouyanni $1990^{3}$ & Athens 1975-1982 & $\mathrm{SO}_{2}$, black smoke & Higher respiratory and CVS mortality on polluted days \\
\hline Kinney $1991^{4}$ & Los Angeles County 1970-1979 & Particles, $\mathrm{CO}, \mathrm{NO}_{2}$ & Strongly associated with daily CVS mortality \\
\hline Schwartz $1992^{5}$ & Philadelphia 1973-1980 & $\begin{array}{l}\mathrm{SO}_{2} \\
\mathrm{TSP}\end{array}$ & $\begin{array}{l}5 \% \uparrow \text { mortality } / 100 \mu \mathrm{g} \uparrow \\
7 \% \uparrow \text { mortality } / 100 \mu \mathrm{g} \uparrow, 10 \% \uparrow \mathrm{CVS} \text { mortality }\end{array}$ \\
\hline Dockery $1993^{6}$ & 6 US cities & Fine particles, sulfates & $\begin{array}{l}\text { Association between cardiopulmonary mortality and level of pollution } \\
\text { in city }\end{array}$ \\
\hline Schwartz $1994^{7}$ & $\begin{array}{l}\text { Philadelphia death certificates } \\
\text { 1973-1980 }\end{array}$ & TSP & $\begin{array}{l}\text { RR death }=1.08 \text { on high } v \text { low pollution day, } \uparrow \text { heart disease and } \\
\text { stroke deaths }\end{array}$ \\
\hline Schwartz $1994^{8}$ & Meta-analysis & TSP & RR death $=1.06$ for $100 \mu \mathrm{g} \uparrow$ \\
\hline Anderson $1996^{9}$ & London 1987-1992 & $\begin{array}{l}\text { Black smoke } \\
\mathrm{SO}_{2} \\
\text { Ozone }\end{array}$ & $\begin{array}{l}2.5 \% \uparrow \text { daily mortality } / 7-19 \mu \mathrm{g} / \mathrm{m}^{3} \uparrow \\
\mathrm{SO}_{2} \text { also significant } \\
3.6 \% \uparrow \mathrm{CVS} \text { mortality } / 7-36 \mathrm{~PB} \uparrow\end{array}$ \\
\hline Ponka $1998^{10}$ & Helsinki 1987-1993 & $\mathrm{PM}_{10}$ & $4.1 \% \uparrow$ CVS mortality $/ 10 \mu \mathrm{g} / \mathrm{m}^{3} \uparrow$ \\
\hline & & $\begin{array}{l}\text { Ozone } \\
\mathrm{NO}_{2}\end{array}$ & $\begin{array}{l}9.9 \% \uparrow \mathrm{CVS} \text { mortality } / 20 \mathrm{\mu g} / \mathrm{m}^{3} \uparrow \\
\text { Additive effect with } \mathrm{PM} 10 \text { and ozone }\end{array}$ \\
\hline Zmirou $1998^{11}$ & 10 European cities & $\begin{array}{l}\text { Black smoke } \\
\mathrm{SO}_{2}\end{array}$ & $\begin{array}{l}\text { RR CVS mortality } 1.02 / 50 \mu \mathrm{gg} / \mathrm{m}^{3} \uparrow \\
\text { RR CVS mortality } 1.04 / 50 \mu \mathrm{gg} / \mathrm{m}^{3} \uparrow\end{array}$ \\
\hline Ostro $1999^{12}$ & Bangkok 1992-1995 & $\mathrm{PM}_{10}$ & $2 \% \uparrow$ CVS mortality $/ 10 \mu \mathrm{g} / \mathrm{m}^{3} \uparrow$ \\
\hline Rossi $1999^{13}$ & Milan 1980-1989 & TSP & $\begin{array}{l}7 \% \uparrow \text { heart failure deaths } / 100 \mu \mathrm{gg} / \mathrm{m}^{3} \uparrow, 10 \% \uparrow \text { myocardial } \\
\text { infarction mortality } / 100 \mu \mathrm{g} / \mathrm{m}^{3} \uparrow\end{array}$ \\
\hline Samet $2000^{14}$ & $20 \mathrm{U}$ cities 1987-1994 & $\mathrm{PM}_{10}$ & $\begin{array}{l}\uparrow \text { Rate of CVS/respiratory mortality, } 0.68 \% \text { for each } \uparrow \mathrm{PM}_{10} \text { of } \\
10 \mu \mathrm{gg} / \mathrm{m}^{3}\end{array}$ \\
\hline Kwon $2001^{15}$ & Seoul 1994-1998 & $\begin{array}{l}\mathrm{SO}_{2}, \mathrm{CO}, \text { ozone, } \mathrm{NO}_{2} \\
\mathrm{PM}_{10}, \mathrm{SO}_{2} \\
\mathrm{CO}_{1} \text { ozone } \\
\mathrm{NO}_{2}\end{array}$ & $\begin{array}{l}\text { Weak associations } \\
\text { RR mortality } 1.014 / \mathrm{IQR} \uparrow \mathrm{PM}_{10} \\
\mathrm{RR} \text { mortality } 1.020 / \mathrm{IQR} \uparrow \mathrm{CO} \\
\text { Effect } 2.5-4.1 \% \text { higher in CCF }\end{array}$ \\
\hline Katsouyanni $2001^{16}$ & 29 European cities APHEA 2 & $\mathrm{PM}_{10}$ & $\begin{array}{l}\uparrow \text { Rate of CVS/respiratory mortality } 0.6 \% \text { for each } \uparrow \mathrm{PM}_{10} \text { of } \\
10 \mu \mathrm{gg} / \mathrm{m}^{3} \text {, effect size greater in elderly, with high } \mathrm{NO}_{2} \text {, or in cold } \\
\text { climates }\end{array}$ \\
\hline
\end{tabular}

APHEA, Air Pollution and Health: a European approach; CCF, congestive cardiac failure; CVS, cardiovascular system; IQR, interquartile range; RR; relative risk; TSP, total suspended particles.

Table 3 Hospital admissions for cardiovascular disease

\begin{tabular}{|c|c|c|c|}
\hline Time series study & Geographic area & Pollutants & Effect on CVS admissions \\
\hline Schwartz $1995^{18}$ & Michigan 1986-1989 & $\mathrm{PM}_{10}, \mathrm{CO}$ & $\begin{array}{l}\uparrow \text { Ischaemic heart disease admissions (RR } 1.018 \text { IQR } \uparrow \mathrm{PM}_{10} \text { ) and with heart } \\
\text { failure (RR } 1.024 / \mathrm{IQR} \uparrow \mathrm{PM}_{10} \text { and } 1.022 / \text { IQR } \uparrow \mathrm{CO} \text { ) }\end{array}$ \\
\hline Burnett $1995^{19}$ & Ontario 1983-1988 & Particulate sulfates & $2.8 \% \uparrow$ CVS admission $/ 13 \mu \mathrm{g} / \mathrm{m}^{3} \uparrow$ \\
\hline Morris $1995^{20}$ & 7 US cities 1986-1989 & $\mathrm{CO}$ & $\uparrow$ Heart failure admissions (RR $1.10-1.37 / 10 \mathrm{ppm} \uparrow$ ) \\
\hline Wordley $1997^{21}$ & Birmingham 1992-1994 & $\mathrm{PM}_{10}$ & $\begin{array}{l}\uparrow \text { Risk of respiratory }(2.4 \%) \text { or cerebrovascular }(2.1 \%) \text { admission for } \\
10 \mu \mathrm{g} / \mathrm{m}^{3} \uparrow\end{array}$ \\
\hline Schwartz $1997^{22}$ & Tuscon 1997 & $\begin{array}{l}\mathrm{PM}_{10} \\
\mathrm{CO}\end{array}$ & $\begin{array}{l}2.75 \% \uparrow \text { CVS admission/IQR } \uparrow \\
2.79 \% \uparrow \mathrm{CVS} \text { admission/IQR } \uparrow\end{array}$ \\
\hline & & Ozone $/ \mathrm{SO}_{2}$ & Little association \\
\hline Burnett $1997^{23}$ & 10 Canadian cities 1981-1991 & & RR heart failure admission $1.065 / \mathrm{IQR} \uparrow$ \\
\hline $\begin{array}{l}\text { Burneft } 1997^{24} \\
\text { Poloniecki } 1997^{25}\end{array}$ & $\begin{array}{l}\text { Toronto } 1992-1994 \\
\text { London 1987-1994 }\end{array}$ & $\begin{array}{l}\text { Ozone, } \mathrm{NO}_{2}, \mathrm{SO}_{2} \\
\text { Black smoke }\end{array}$ & $\begin{array}{l}13 \% \uparrow \mathrm{CVS} \text { admissions/IQR } \uparrow \text { gaseous pollutants } \\
2.5 \% \text { myocardial infarction admissions attributable, associated with angina } \\
\text { admissions }\end{array}$ \\
\hline Schwartz $1999^{26}$ & Eight US counties 1988-1990 & $\begin{array}{l}\mathrm{NO}_{2} \\
\mathrm{PM}_{10} \\
\mathrm{CO}\end{array}$ & $\begin{array}{l}\text { Associated with arrhythmia admissions } \\
2.48 \% \uparrow \mathrm{CVS} \text { admission/IQR } \uparrow \\
2.79 \% \uparrow \mathrm{CVS} \text { admission/IQR } \uparrow\end{array}$ \\
\hline
\end{tabular}


significantly correlated with increased $\mathrm{PM}_{10}$ and $\mathrm{PM}_{2.5}$, with a lag time of two days, and with nitrogen dioxide on the previous day. In patients with at least 10 interventions to treat ventricular arrhythmia, the odds of a discharge tripled with an increase in nitrogen dioxide from the 5th to 95th centile and increased by $60 \%$ for an equivalent rise in $\mathrm{PM}_{2.5}$.

The relation between air pollution and myocardial infarction has recently been strengthened by the findings of the determinants of myocardial infarction onset study. ${ }^{33}$ This multicentre, case crossover investigation suggested that a transient increase in the concentration of fine particles (increase of $25 \mu \mathrm{g} / \mathrm{m}^{3} \mathrm{PM}_{2.5}$ ) —still below current air quality standards - was associated with an increased risk (odds ratio 1.48) of myocardial infarction within 1-2 hours. In addition high 24 hour concentrations of fine particles were associated with an increased risk (odds ratio 1.69) of myocardial infarction. The results at the two separate time periods were independent and additive suggesting the possibility of two, possibly independent, mechanisms.

\section{POTENTIAL MECHANISMS}

Epidemiology has clearly shown a link between increases in particulate air pollution and deaths and admissions caused by heart failure, myocardial infarction, and arrhythmia. To show that these associations are causal, plausible mechanisms of action are required. Several hypotheses have been proposed, and evidence is accumulating in support of two possibly interlinked mechanisms by which low concentrations of particles in inspired air may have adverse cardiovascular effects. Inhalation and interstitialisation of fine particles may provoke an inflammatory response in the lungs with the consequent release into the circulation of prothrombotic and inflammatory cytokines. A systemic acute phase response of this nature would put people with coronary atheroma at increased risk of plaque rupture and thrombosis. Secondly, exposure to PM may have an adverse effect on cardiac autonomic control, leading to an increased risk of arrhythmia in susceptible patients.

\section{INFLAMMATION AND COAGULATION}

A systemic inflammatory response to particulate air pollution was initially suggested in 1995 by Seaton and colleagues ${ }^{34}$ who postulated that such a response may precipitate acute coronary events as a result of an increase in blood coagulability. The relation between systemic inflammation and adverse coronary events both in patients with coronary artery disease $e^{35}{ }^{36}$ and in the general population ${ }^{37}$ is now well established. The analysis of stored blood samples from the subjects of large epidemiological studies has provided evidence for a systemic inflammatory response to air pollutants. Both plasma viscosity and $\mathrm{C}$ reactive protein concentration increased in association with high levels of particulate pollution in studies involving nearly 4000 healthy adults. $^{38} 39$ During an air pollution episode, the odds of observing $\mathrm{C}$ reactive protein concentrations above the 90th centile increased threefold, and the odds ratio for plasma viscosity above the 95th centile of the distribution was 3.6. These associations suggest that pulmonary injury as a result of pollution may lead to a systemic inflammatory response. The pulmonary insult initiating such a sequence of events has been shown by exposure studies at both the cellular and animal level. Fine particles have been shown to be able to penetrate the alveolar epithelium ${ }^{40}$ causing local inflammation and oxidative stress. ${ }^{41}$ Human bronchial epithelial cells exposed to combustion derived particles in vitro release proinflammatory cytokines such as interleukin 6, interleukin 8 , and tumour necrosis factor $\alpha{ }^{42}{ }^{43}$ Cytokine production in these models is preceded by activation of the transcription factor nuclear factor $\kappa \mathrm{B}^{4445}$ and is inhibited by the free radical scavenger $N$-acetyl-L-cysteine. ${ }^{46}$

In animals, ambient $\mathrm{PM}_{10}$ samples collected and then administered by intratracheal instillation have enabled closer investigation of the properties of particles that are responsible for causing an inflammatory response. ${ }^{47}$ The degree of oxidative stress and the release of cytokines have consistently been found to be related to size, surface area, and the transition metal content of particles. ${ }^{48}{ }^{49}$ The oxidant and proinflammatory properties of particles remain an active area of research, while the systemic and cardiac consequences of this pulmonary injury are now also being examined experimentally. In healthy human volunteers, increases in neutrophils and platelets in the peripheral blood have been found following acute exposure to diesel exhaust, in association with an increase in inflammatory cells and expression of endothelial adhesion molecules in bronchial biopsies. $^{50}$ In hyperlipidaemic rabbits, exposure to $\mathrm{PM}_{10}$ caused bone marrow stimulation, with an increase in circulating polymorphonuclear leucocytes. In addition, atherosclerotic lesions in these animals displayed characteristic features of instability (thin plaque caps, presence of inflammatory cells, fewer smooth muscle cells) when compared with lesions in non-exposed controls. ${ }^{51}$

Recently, the assumption that local pulmonary inflammation following pollution exposure is the sole trigger of the systemic inflammatory response has been challenged. Ultrafine carbon particles radiolabelled with $99 \mathrm{~m}$ technetium were found to pass rapidly into the systemic circulation following inhalation..$^{52}$ Accumulation in the liver, perhaps by Kupffer cells, suggests that inflammation in response to pollution may be initiated at extrapulmonary sites. Animal and human challenge studies should further clarify the nature of the proinflammatory and procoagulant cytokine responses to inhalation of specific pollutants.

\section{CARDIAC AUTONOMIC CONTROL}

Disturbances in the control of heart rate and rhythm in response to particulate pollution were originally suggested by two observational studies. Increases in heart rate in nearly 3000 subjects were observed during a pollution episode in Central Europe in January 1985. ${ }^{1}$ In a panel study in Utah, pulse rate (and the likelihood of the pulse rate being increased) were positively associated with levels of $\mathrm{PM}_{10}$ on the preceding one to five days. ${ }^{53}$ An increase in resting heart rate suggests either reduced vagal or increased sympathetic cardiac control and is recognised as an independent risk factor for total cardiovascular mortality and sudden death. $^{5455}$ The mechanisms by which abnormal autonomic control influence prognosis are not proven, but there is strong animal evidence that increased sympathetic and reduced vagal control results in an increased susceptibility of ischaemic myocardium to ventricular fibrillation. ${ }^{56}$ Thus, these two observational studies provide a plausible link between exposure to particulate pollution and sudden cardiac death in susceptible people.

Experimental animal evidence also supports the hypothesis that the cardiac autonomic nervous system is susceptible to the adverse effects of air pollution. In dogs with partially ligated coronary arteries exposed to concentrated ambient particles through tracheostomy, heart rates rose with increasing $\mathrm{PM}_{10}$ exposure and cardiac autonomic control measured by heart rate variability (HRV) was altered. ${ }^{57}$ Decreased HRV reflects impaired vagal cardiac control and is an independent predictor of cardiac death in patients with established heart disease such as myocardial infarction ${ }^{58}$ and chronic heart failure. ${ }^{59}$ Analysis of ambulatory ECG recording from seven elderly subjects during particulate pollution episodes from a steel mill showed consistent negative 
associations between pollution and same day measures of HRV. ${ }^{60}$ In two further groups of elderly patients, the risk of a person having low HRV was significantly increased on high $\mathrm{PM}_{2.5}$ days. ${ }^{61}{ }^{62}$ In an occupational study, the limitations in estimating personal exposure from regional monitoring were overcome by the use of personal exposure monitors in a cohort of 40 boilermakers. A significant negative association was found between 4 hour $\mathrm{PM}_{2.5}$ exposure and 24 hour standard deviation of normal to normal RR intervals, a standard index of HRV. ${ }^{63}$ Experimental laboratory exposure to sulfur dioxide in humans has also recently been shown to exert significant adverse effects on HRV. ${ }^{64}$

Exactly how inhalation of pollutants and, in particular, fine particles can exert such effects on the cardiac autonomic nervous system remains to be elucidated. Animal work has shown that stimulation of nasopharyngeal, upper, and lower airway receptors can mediate powerful neural influences on the cardiovascular system. ${ }^{65}$ Alternatively, and in keeping with the inflammatory hypothesis, inhaled particles may indirectly promote an autonomic stress response as a result of cytokine release.

These two mechanistic hypotheses in combination may thus explain the observed acute effects of air pollution on cardiovascular morbidity and mortality. In susceptible people, pollution may increase the likelihood of plaque rupture, promote ischaemia, and increase the vulnerability of ischaemic or failing myocardium to lethal arrhythmia (fig 1). ${ }^{66}$

\section{CHRONIC EFFECTS}

The long term effects of air pollution exposure on the cardiovascular system are more difficult to determine but a small number of studies has highlighted potentially important associations. Two large prospective cohort studies have found associations between long term exposure to fine PM and cardiopulmonary mortality. ${ }^{67}$ In the US six cities study involving over 8000 subjects, the effects of air pollution on mortality were estimated while controlling for other risk factors. Over a 16 year follow up period, city specific cardiopulmonary mortality rates were found to be associated with the average concentrations of particulate pollutants in each city. ${ }^{6}$ The American Cancer Society found an association between fine particulate and sulfur oxide pollution and cardiopulmonary mortality after a six year follow up in over 500000 adults. Each $10 \mu \mathrm{g} / \mathrm{m}^{3}$ increase in fine particulate air pollution was associated with a $6 \%$ increase in risk of cardiopulmonary mortality. ${ }^{68}$ Most recently in a study from the Netherlands a consistent association was found between long term exposure to traffic related pollution and cardiopulmonary mortality. Living near a major road and hence being exposed to the highest levels of both black smoke and nitrogen dioxide was associated with a relative risk of cardiopulmonary mortality of $1.95 .{ }^{69}$

The association between long term pollution exposure and cardiovascular death may also be explained by the inflammatory properties of fine particles. In addition to the relation

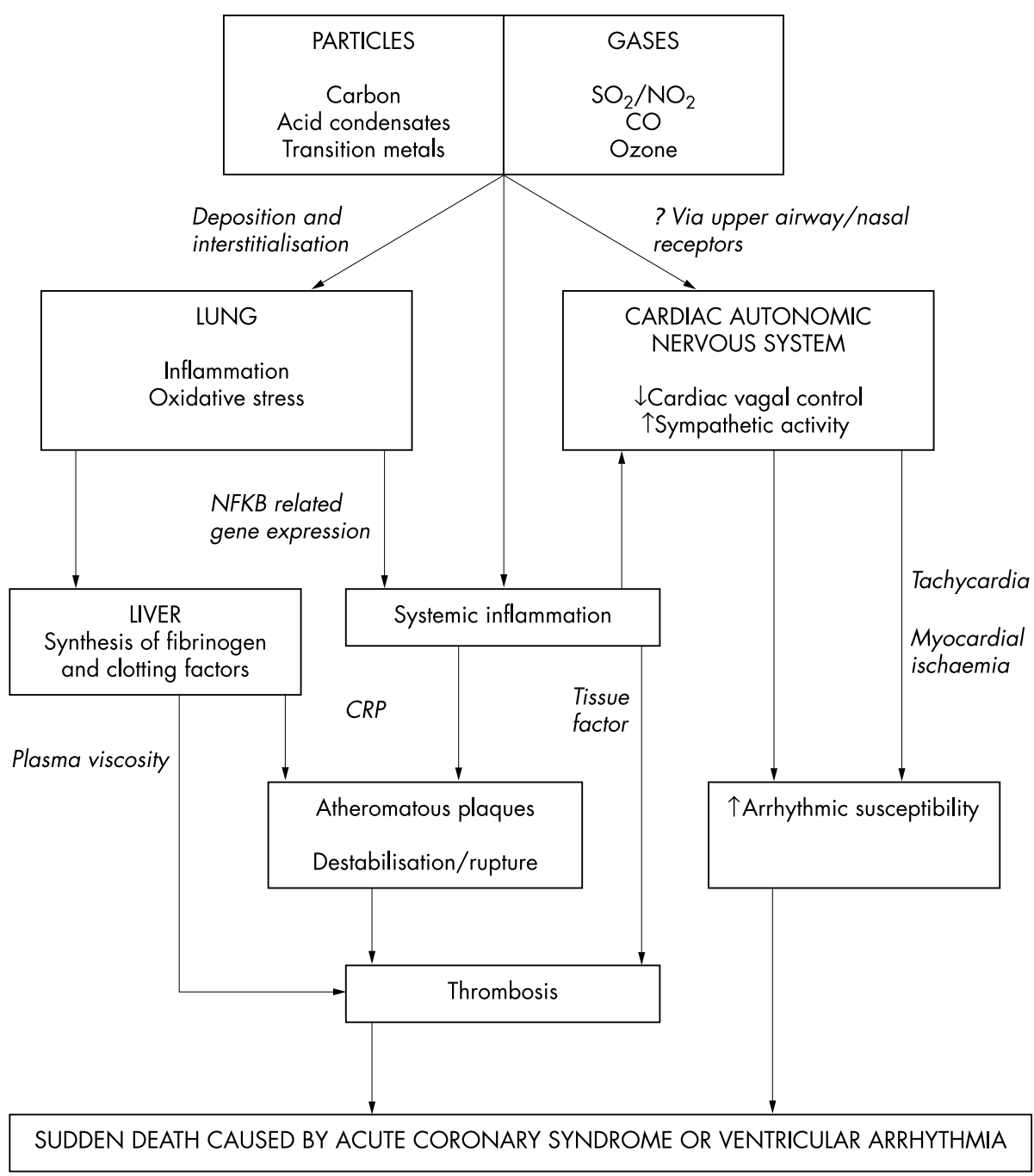

Figure 1 Mechanisms by which particulate and gaseous air pollutants may exert adverse effects on the cardiovascular system. 
between acute cardiac events and inflammatory stimuli, there is growing evidence of the importance of inflammation in the atherogenic process itself. ${ }^{70}$ Markers of inflammation such as $\mathrm{C}$ reactive protein can predict long term cardiovascular mortality in apparently healthy subjects. ${ }^{37}$ In patients undergoing diagnostic coronary angiography, serological evidence of multiple exposure to infectious agents is related to the extent of atherosclerosis and to long term prognosis. ${ }^{71}$ Although this awaits supportive experimental evidence, one may hypothesise that, in a similar manner to cigarette smoking, repeated exposure to pollutants would contribute to a chronic inflammatory state, increasing the propensity to atherogenesis.

\section{FUTURE RESEARCH}

The unpredictable nature of coronary artery disease remains a problem that concerns all cardiologists. Patients with chronic stable angina have a low annual rate of clinical events, but sudden death and acute coronary syndromes including acute myocardial infarction can present without warning both in patients with established disease and in apparently healthy people. Surprisingly little attention has been paid to environmental factors that may influence levels of inflammation and autonomic tone and thus cardiovascular risk. The role of air pollution in determining inflammatory or oxidative status and cardiac autonomic control remains to be determined, but it can be seen that the epidemiological evidence for the association of air pollution with cardiac mortality and morbidity is beyond doubt. Research already underway will throw light upon which components of air pollution are important in these respects and at what levels. The determination of possible threshold effects or "safe" levels will help to establish both appropriate legal standards and the policies required for air quality control. In addition, basic research into exactly how air pollution may result in adverse cardiac events may help to improve our understanding of the triggers of plaque rupture and arrhythmia. Further clinical studies are required but cellular and molecular studies in the field of atherosclerosis and arrhythmia should assess the impact of environmental factors such as air pollution.

\section{Authors' affiliations}

\section{H C Routledge, J N Townend, Division of Medical Sciences}

(Cardiology), University of Birmingham, Queen Elizabeth Hospital, Birmingham, UK

J G Ayres, Department of Environmental \& Occupational Medicine, University of Aberdeen, Foresterhill Road, Aberdeen, UK

\section{REFERENCES}

1 Wichmann HE, Mueller W, Allhoff $P$, et al. Health effects during a smog episode in West Germany in 1985. Environ Health Perspect 1989.79.89-99.

2 Schwartz J, Marcus A. Mortality and air pollution in London: a time series analysis. Am J Epidemiol 1990;131:185-94.

3 Katsouyanni K, Karakatsani A, Messari I, et al. Air pollution and cause specific mortality in Athens. J Epidemiol Community Health 1990;44:321-4.

4 Kinney PL, Ozkaynak H. Associations of daily mortality and air pollution in Los Angeles County. Environ Res 1991;54:99-120.

5 Schwartz J, Dockery DW. Increased mortality in Philadelphia associated with daily air pollution concentrations. Am Rev Respir Dis 1992;145:600-4.

6 Dockery DW, Pope AC 3rd, Xu X, et al. An association between air pollution and mortality in six U.S.cities. N Engl J Med 1993;329:1753-9.

7 Schwartz J. What are people dying of on high air pollution days? Environ Res 1994;64:26-35.

8 Schwartz J. Air pollution and daily mortality: a review and meta analysis. Environ Res 1994:64:36-52.

9 Anderson HR, Ponce de Leon A, Bland JM, et al. Air pollution and daily mortality in London: 1987-92. BMJ 1996;312:665-9.

10 Ponka A, Savela M, Virtanen M. Mortality and air pollution in Helsinki. Arch Environ Health 1998:53:281-6.

11 Zmirou D, Schwartz J, Saez M, et al. Time-series analysis of air pollution and cause-specific mortality. Epidemiology 1998;9:495-503.

12 Ostro B, Chestnut L, Vichit-Vadakan N, et al. The impact of particulate matter on daily mortality in Bangkok, Thailand. J Air Waste Manag Assoc 1999:49:100-7.
13 Rossi G, Vigotti MA, Zanobetti A, et al. Air pollution and cause-specific mortality in Milan, Italy, 1980-1989. Arch Environ Health 1999;54:158-64. 14 Samet JMD, Curriero F, Coursac FC, et al. Fine particulate air pollution and mortality in 20 U.S.cities 1987-1994. N Engl J Med 2000;343:1742-9.

$15 \mathrm{Kwon} \mathrm{HJ}$, Cho SH, Nyberg F, et al. Effects of ambient air pollution on daily mortality in a cohort of patients with congestive heart failure. Epidemiology $2001 ; 12: 413-9$

16 Katsouyanni K, Touloumi G, Samoli E, et al. Confounding and effect modification in the short-term effects of ambient particles on total mortality: results from 29 European cities within the APHEA2 project. Epidemiology $2001 ; 12: 521-31$

17 Dockery DW. Epidemiologic evidence of cardiovascular effects of particulate air pollution. Environ Health Perspect 2001;109(suppl 4):483-6.

18 Schwartz J, Morris R. Air pollution and hospital admissions for cardiovascular disease in Detroit, Michigan. Am J Epidemiol 1995; 142:23-35.

19 Burnett RT, Dales R, Krewski D, et al. Associations between ambient particulate sulfate and admissions to Ontario hospitals for cardiac and respiratory diseases. Am J Epidemiol 1995;142:15-22.

20 Morris RD, Naumova EN, Munasinghe RL. Ambient air pollution and hospitalization for congestive heart failure among elderly people in seven large US cities. Am J Public Health 1995;85:1361-5.

21 Wordley J, Walters S, Ayres JG. Short term variations in hospital admissions and mortality and particulate air pollution. Occup Environ Med 1997;54:108-16.

22 Schwartz J. Air pollution and hospital admissions for cardiovascular disease in Tucson. Epidemiology 1997;8:371-7.

23 Burnett RT, Dales RE, Brook JR, et al. Association between ambient carbon monoxide levels and hospitalizations for congestive heart failure in the elderly in 10 Canadian cities. Epidemiology 1997;8:162-7.

24 Burnett RT, Cakmak S, Raizenne ME, et al. The association between ambient carbon monoxide levels and daily mortality in Toronto, Canada. J Air Waste Manage Assoc 1998:48:689-700.

25 Poloniecki JD, Atkinson RW, de LAP, et al. Daily time series for cardiovascular hospital admissions and previous day's air pollution in London, UK. Occup Environ Med 1997;54:535-40.

26 Schwartz J. Air pollution and hospital admissions for heart disease in eight U.S.counties. Epidemiology 1999;10:17-22.

27 Anderson HA RW. Association between ambient particles and daily admissions for cardiovascular diseases. London: Department of Health, 2001.

28 Clancy L, Goodman P, Sinclair H, et al. Effect of air-pollution control on death rates in Dublin, Ireland: an intervention study. Lancet 2002;360:1210-4.

29 Hedley AJ, Wong CM, Thach TQ, et al. Cardiorespiratory and all-cause mortality after restrictions on sulphur content of fuel in Hong Kong: an intervention study. Lancet 2002;360:1646-52.

30 Goldberg MS, Burnett RT, Bailar JC 3rd, et al. Identification of persons with cardiorespiratory conditions who are at risk of dying from the acute effects of ambient air particles. Environ Health Perspect 2001;109(suppl 4):487-94.

31 Hoek G, Brunekreef B, Fischer $P$, et al. The association between air pollution and heart failure, arrhythmia, embolism, thrombosis, and other cardiovascular causes of death in a time series study. Epidemiology 2001;12:355-7.

32 Peters A, Liu E, Verrier RL, et al. Air pollution and incidence of cardiac arrhythmia. Epidemiology 2000;11:11-7.

33 Peters A, Dockery DW, Muller JE, et al. Increased particulate air pollution and the triggering of myocardial infarction. Circulation 2001;103:2810-5.

34 Seaton A, MacNee W, Donaldson K, et al. Particulate air pollution and acute health effects. Lancet 1995;345:176-8.

35 Ferreiros EB, Boissonnet CP, Pizarro R, et al. Independant prognostic value of elevated $\mathrm{C}$-reactive protein in unstable angina. Circulation 1999; 100:1958-63.

36 Biasucci LLG. Elevated levels of C-reactive protein at discharge in patients with unstable angina predict recurrent instability. Circulation 1999;99:855-60.

37 Ridker PM, Hennekens $\mathrm{CH}$, Buring JE, et al. C-reactive protein and other markers of inflammation in the prediction of cardiovascular disease in women. N Engl J Med 2000;342:836-43.

38 Peters A, Doring A, Wichmann HE, et al. Increased plasma viscosity during an air pollution episode: a link to mortality? Lancet 1997;349:1582-7.

39 Peters A, Frohlich M, Doring A, et al. Particulate air pollution is associated with an acute phase response in men: results from the MONICA-Augsburg study. Eur Heart J 2001;22:1198-204.

40 Donaldson KLX, MacNee W. Ultrafine (nanometre) particle mediated lung injury. J Aerosol Sci 1998;29:553-60.

41 Donaldson K. Studies on the inflammatory potential of fine and ultrafine particles of carbon black, titanium dioxide and polystyrene/latex [abstract] Am J Respir Crit Care Med 2000;161:A911.

42 Veronesi B, Oortgiesen M, Carter JD, et al. Particulate matter initiates inflammatory cytokine release by activation of capsaicin and acid receptors in a human bronchial epithelial cell line. Toxicol Appl Pharmacol 1999; 154:106-15.

43 Jimenez LA, Drost EM, Gilmour PS, et al. PM(10)-exposed macrophages stimulate a proinflammatory response in lung epithelial cells via TNF-alpha. A J Physiol Lung Cell Mol Physiol 2002;282:L237-48.

44 Kennedy T, Ghio AJ, Reed W, et al. Copper-dependent inflammation and nuclear factor-kappaB activation by particulate air pollution. Am J Respir Cell Mol Biol 1998:19:366-78.

45 Shukla A, Timblin C, Berube K, et al. Inhaled particulate matter causes expression of nuclear factor kappa $B$ related genes and oxidant dependent NF kappa B activation in vitro. Am J Respir Cell Mol Biol 2000;23:182-7.

46 Quay JL, Reed W, Samet J, et al. Air pollution particles induce IL-6 gene expression in human airway epithelial cells via NF-kappaB activation. Am J Respir Cell Mol Biol 1998;19:98-106. 
47 Costa DL, Dreher KL. Bioavailable transition metals in particulate matter mediate cardiopulmonary injury in healthy and compromised animal models. Environ Health Perspect 1997;5:1053-60

48 Frampton MW, Ghio AJ, Samet JM, et al. Effects of aqueous extracts of PM(10) filters from the Utah valley on human airway epithelial cells. Am J Physiol 1999;277:L960-7.

49 Ghio AJ, Richards JH, Carter JD, et al. Accumulation of iron in the rat lung after tracheal instillation of diesel particles. Toxicol Pathol 2000;28:619-27.

50 Salvi S, Blomberg A, Rudell B, et al. Acute inflammatory responses in the airways and peripheral blood after short-term exposure to diesel exhaust in healthy human volunteers. Am J Respir Crit Care Med 1999;159:702-9.

51 Suwa T, Hogg JC, Quinlan KB, et al. Particulate air pollution induces progression of atherosclerosis. J Am Coll Cardiol 2002;39:935-42.

52 Nemmar A, Hoet PH, Vanquickenborne B, et al. Passage of inhaled particles into the blood circulation in humans. Circulation 2002;105:411-4.

53 Pope CA 3rd, Dockery DW, Kanner RE, et al. Oxygen saturation, pulse rate, and particulate air pollution: a daily time-series panel study Am J Respir Crit Care Med 1999; 159:365-72.

54 Dyer AR, Persky V, Stamler J, et al. Heart rate as a prognostic factor for coronary heart disease and mortality: findings in three Chicago epidemiologic studies. Am J Epidemiol 1980;1 12:736-49.

55 Hjalmarson A, Gilpin EA, Kjekshus J, et al. Influence of heart rate on mortality after acute myocardial infarction. Am J Cardiol 1990;65:547-53.

56 Schwartz P, Vanoli E, Stramba-Badiale M, et al. Autonomic mechanisms and sudden death: new insights from analysis of baroreceptor reflexes in conscious dogs with and without a myocardial infarction. Circulation 1988;78:969-79.

57 Godleski JJ, Verrier RL, Koutrakis P, et al. Mechanisms of morbidity and mortality from exposure to ambient air particles. Res Rep Health Eff Inst 2000;Feb:5-88

58 La Rovere M, Bigger JT Jr, Marcus Fl, et al. Baroreflex sensitivity and heartrate variability in prediction of total cardiac mortality after myocardial infarction. ATRAMI (autonomic tone and reflexes after myocardial infarction) Investigators. Lancet 1998:351:478-84.

59 Nolan J, Batin PD, Andrews R, et al. Prospective study of heart rate variability and mortality in chronic heart failure: results of the United Kingdom heart failure evaluation and assessment of risk trial (UK-heart). Circulation 1998;98:1510-6.

60 Pope CA 3rd, Verrier RL, Lovett EG, et al. Heart rate variability associated with particulate air pollution. Am Heart J 1999:138:890-9.

61 Liao D, Creason J, Shy C, et al. Daily variation of particulate air pollution and poor cardiac autonomic control in the elderly. Environ Health Perspect 1999; 107:521-5

62 Gold DR, Litonjua A, Schwartz J, et al. Ambient pollution and heart rate variability. Circulation 2000;101:1267-73.

63 Magari SR, Hauser R, Schwartz J, et al. Association of heart rate variability with occupational and environmental exposure to particulate air pollution. Circulation 2001;104:986-91.

64 Tunnicliffe WS, Hilton MF, Harrison RM, et al. The effect of sulphur dioxide exposure on indices of heart rate variability in normal and asthmatic adults. Eur Respir J 2001;17:604-8.

65 Yeates DB, Mauderly JL. Inhaled environmental/occupational irritants and allergens: mechanisms of cardiovascular and systemic responses. Introduction. Environ Health Perspect 2001;109(suppl 4):479-81.

66 Zareba W, Nomura A, Couderc JP. Cardiovascular effects of air pollution: what to measure in ECG? Environ Health Perspect 2001;109(suppl 4):533-8.

67 Pope CA 3rd, Thun MJ, Namboodiri MM, et al. Particulate air pollution as a predictor of mortality in a prospective study of U.S.adults. Am J Respir Crit Care Med 1995; 151:669-74.

68 Pope CA 3rd, Burnett RT, Thun MJ, et al. Lung cancer, cardiopulmonary mortality, and long-term exposure to fine particulate air pollution. JAMA 2002;287:1132-41

69 Hoek G, Brunekreef B, Goldbohm S, et al. Association between mortality and indicators of traffic-related air pollution in the Netherlands: a cohort study. Lancet 2002;360:1203-9.

70 Ross R. Atherosclerosis: an inflammatory disease. N Engl J Med 1999;340:115-25.

71 Espinola-Klein C, Rupprecht HJ, Blankenberg S, et al. Impact of infectious burden on extent and long-term prognosis of atherosclerosis. Circulation 2002; 105: 15-21

\section{IMAGES IN CARDIOLOGY}

\section{Pulmonary artery sarcoma}

A 38 year old man without any symptoms was referred to our hospital for examination of a heart murmur. There were signs of right ventricular overload on the ECG. Doppler echocardiographic measurements demonstrated a maximum pressure gradient of $105 \mathrm{~mm} \mathrm{Hg}$ across the right ventricular outflow tract. Lung perfusion scanning demonstrated reduced tracer uptake in the right lung. Although we initially suspected pulmonary thromboembolism, the computed tomographic angiography revealed severe luminal stenosis and a solid mass arising from the right ventricular outflow tract extending into both left and right pulmonary arteries (see fig), which are atypical findings for pulmonary thromboembolism. The morphological characteristics detected by computed tomography suggested the diagnosis of pulmonary artery sarcoma. After intraoperative pathologic examination of the frozen section confirmed the diagnosis of pulmonary artery sarcoma, radical resection and reconstructive surgery using a cryopreserved homograft were performed. The patient received postoperative radiotherapy and chemotherapy, and has remained well over the subsequent 10 months.

Pulmonary artery sarcoma is extremely rare and has a poor prognosis. The diagnosis is difficult and often initially misdiagnosed as pulmonary thromboembolism. It has been reported that a mean survival is only 1.5 months after diagnosis without surgical intervention. Early diagnosis and aggressive surgical treatment are the only ways of effecting

a cure. Computed tomography may offer adequate information on the extent of a neoplasm, which helps us to differentiate a pulmonary artery sarcoma from pulmonary thromboembolism.

\section{N Kotooka N Nagaya R Tanaka nagayann@hsp.ncvc.go.jp}
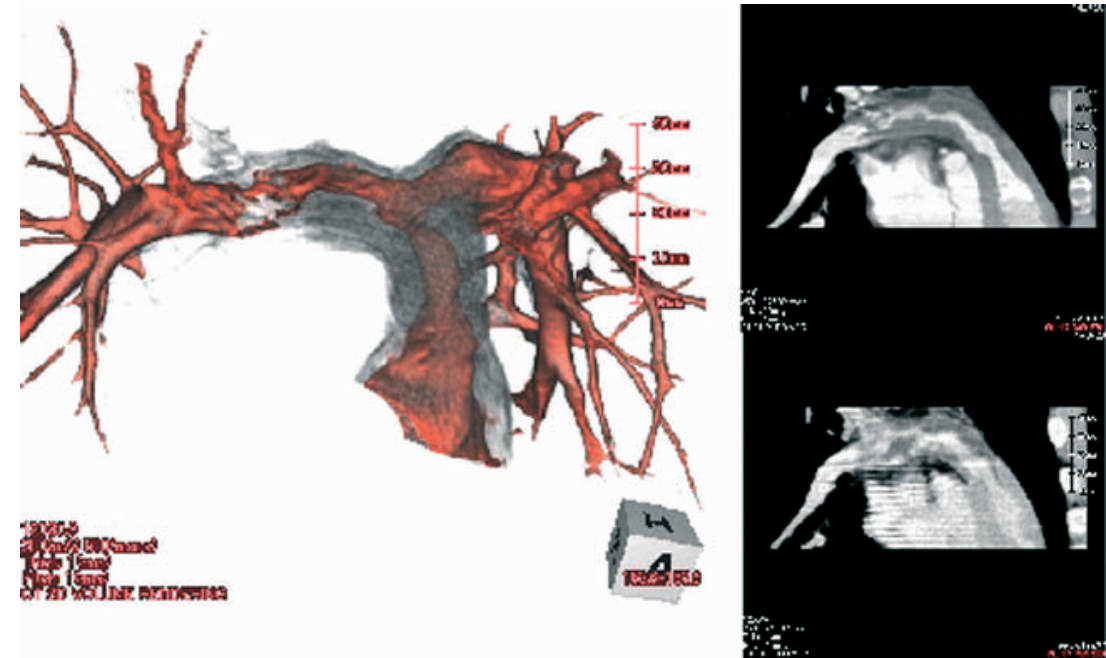